\title{
SUSTAINABLE STRATEgIC PLANNING PRINCIPLES OF COLLEGES
}

Intra Luce ${ }^{1}$, M.iur

${ }^{1}$ Riga, Latvia College of Law, Latvia.

\begin{abstract}
At present, the concept of sustainable development is the key issue in all documents, including educational development planning guidelines, at the global, European and national levels. Sustainability has become a decisive factor for choosing strategies, drawing up development, action and investment plans. Sustainable development planning involves the use of many variables, forecasting and implementation of a systemic approach. Colleges develop their long-term development strategies for a certain period of time. A college mission could, in this case, be considered the "cornerstone" of an educational institution. Apart from defining a mission, it is indispensable to set strategic planning methods, principles and, not least important, vision and values. The aim of the article is to reflect and analyse the three main elements within the sustainable strategic planning of colleges - mission, vision, and values. Under the frame of sustainable development planning at colleges, the task of this article is to draw attention to mission and vision of colleges, to analyze mission and vision from the aspect of their definement and simultaneously to conduct a research of mission and vision of all colleges in Latvia and their correspondence definitions and objectives revolved on them. Within the framework of the research, general scientific research methods have been used: analysis, synthesis and logical construction methods.
\end{abstract}

Key words: administration, sustainable development, mission, vision, college.

JEL code: $M 1$

\section{Introduction}

A wide range of definitions of a strategy are available in the scientific literature (Klaus A., 2002; Steven R., 2008). A common idea in all definitions is that a strategy is a plan and a principle of action, a set of activities to be carried out covering all areas and directions of the organisation, which reflect measures for sustainable development. The existence of a strategy is the basis for implementing the organisation's competitive advantage. It is difficult to formulate a good definition of a strategy. This is also indicated by strategy and business consultant Neville Leigh (2007). A lot of managers focus on grand strategic dilemmas. They offer ideas on how to create a new product, such as an educational programme, a new model of cooperation between different educational institutions and entrepreneurs, in order to achieve a win-win situation in competition with other educational institutions. However, in the proposed variants the strategy often remains on paper and does not become reality due to several reasons: insufficient assessment of the situation, resources are limited, the manager is not interested in managing the change processes, the colleagues are dismissive, who in the foreseen implementation of the strategy see threats to their status, the fear of change, because it is impossible to predict the possible consequences, which may not meet expectations. At present, there are 26 colleges in Latvia that implement short-cycle professional higher education and the college's mission, vision and values play an important role in ensuring the successful operation of each college. What is not always clearly defined and as it can be concluded from the information available at colleges' websites it is often difficult to distinguish the college's mission from vision, values and the goals set. The article will reflect the abovementioned theoretical aspects and the authors' views, as well as provide an overview of the colleges' mission and vision statements. Uniform strategic planning does not promote competitiveness and quality. 


\section{Mission, vision and values}

Sustainable development consists of at least three dimensions or spheres: social, economic and environmental dimensions, but some sources also mention four and even more dimensions, adding to the above-mentioned list the political dimension and highlighting the cultural dimension. All dimensions are interdependent and closely related; they interact with each other, i.e., changes in one dimension also cause changes in other dimensions. A systematic approach to the concept of sustainable development calls for an extended approach to understanding of the factors influencing sustainable development. Development planning documents are increasingly focusing on the human factor defined as the sustainable development of human resources or human capital. However, with regard to the three main dimensions, the economic one is undeniably important, since daily reality shows that competition is becoming global with each passing day. And here one of the benefits to sustainable development of the economy/business is socially responsible behaviour; therefore, socially responsible strategy planning is essential for the sustainable development of the company.

According to the classical theory of strategic planning, the beginning stage of strategic planning is the determination of a company's mission, which serves as a concentrated definition of the company's existence and defines the general direction of development. The mission and values of the company reflect the principles of entrepreneurial virtue and morality. The mission should, to a greater or lesser extent, reflect the needs of all strategic stakeholders. Undoubtedly, the manifestation of these entities' interests depends on the size of the company, its location, the sector represented etc. (Kochanova R., 2012).

However, with regard to the company's sustainable development and strategic planning it is not enough to discuss only mission. It is important to consider the three principles: mission (from Latin missio - to send), vision (from Latin visio - to see) and values.

Mission, vision and values are the basic tools of organisation management. The mission and values are the main elements, which justify the existence of the company, institution, organisation and the importance of person's belonging to one of them. The mission of the company, institution and organisation is the precisely defined main aim of the organisation as a whole. It should be emotional enough, it should justify why you and your staff are coming to work. If the formulation of the mission is similar to other companies' mission statements, boring and formal, then it does not make sense.

In the traditional (Drucker P., King V., and Cleland D.I.) and modern understanding of the management (Leigh N., 2007.), mission is a public operation, the main task that needs to be done for the benefit of the community.

Typically, the mission is formulated in an abstract and general way; it does not contain concrete measures, but reflects the general direction, motivation for action, creates the image of the institution, the idea that its operation is acceptable to the public, that the institution is successful and worthy of trust and support.

In daily practice, it is generally assumed that the mission is formulated by the company manager, a team created by the manager. However, this type of policy does not always reflect the whole company, institution, or organisation's perception of what a company's mission is. Consequently, if the company's management involves all employees and social partners in the development of the mission, it becomes one's own personal value, symbolises belonging to the team and promotes cooperation in achieving the common goal. Before the mission is formulated, 
each institution needs to find out what the prospective action model will be. Neville Leigh (2007) offers four possible choices:

- to be almost the same but become better (to improve);

- to be almost the same but become larger (to expand);

- to keep some existing parts and add new parts (to develop);

- to substantially change (to re-establish).

The formulation of the vision is usually much shorter than the mission. It is like a visual image that shows what kind of organisation we are willing to be, in what atmosphere to work. Vision introduces the organisation's main development directions to employees and clients, partners and the general public. Vision provides guidelines for the basic things that need to be protected and those that need to be changed in the future.

The vision is an image of illusions and dreams, a phenomenon, a concise formulation of the organisation's desired future, a landmark for development (Klaus A., 2002). It can be seen that the proposed general formulation of the vision shows depth of its content and, possibly, the various approaches to its explanation. Neville Leigh (2007) offers the original definition of the vision, "Vision is the highest expectations and ideals of the organisation, what the organisation is willing to become. The formulation often describes the organisation's elevated, even romantic and mythical nuances". Usually institutions perceive the vision as an ideal, general purpose, which serves as a landmark for what to strive.

The definition of vision is usually shorter; it does not require much effort as a mission statement. To be effective, the formulation of the vision should be (Dzedons A., 2003):

- significant (one that is important to the management team);

- well-known (it should be communicated to the customer, social partners and institution's staff;

- stimulating (one that would create a desire to get involved and participate);

- reliable (based on reality);

- picturesque (to stick in memory and be associated with a particular institution). Often the vision is formulated simultaneously with the development of the mission.

Undeniably, the essence of a sustainable enterprise, institution and organisation is rooted in basic values that do not change over time. The purpose of such existence is not just to make money. Values substantiate deeper meaning of existence and significance for both the organisation's employees and the society as a whole.

Sustainable organisations distinguish their core values and their main goal/mission, which never changes, from their business strategies and action practices, which need to change constantly to respond to the changing world's impact. A clear vision and mission allow making productive changes without losing core values. The importance of this concept has proven to be quite dramatic, for example, in the lives of companies such as Walt Disney in 1939, 1980; Boeing in the 1930s, in the late 1940s and again in the early 1970s; Hewlet-Packard in 1945 and 1990; Sony from 1945 to 1950 and again in 1970. These are interesting and evidence-rich stories worth being familiar with in order to better understand one's own organisation. They have passed the test of time, difficult circumstances and situations.

This applies both to large and small businesses - to make productive changes without destroying the core values. Radical changes in business activities, cultural norms and business strategies do not mean the loss of basic principles. 


\section{Mission, vision and values of colleges}

In preparation for battle, I have always found that plans are useless, but planning is indispensable.

/Dwight David

Eisenhower

Thirty-Fourth President of the United

States/

The author has examined the information on the colleges' mission available at the websites of the colleges in Latvia, who implement short-cycle professional higher education. Within the framework of the study, 25 colleges' websites have been studied; 3 colleges do not provide information about their mission, vision and values at their websites.

As far as strategic planning is concerned, starting a planning process each college management should first answer the following questions:

- Who are the partners in providing services? How will service users participate in the planning?

- What services do people need?

- What is the capacity of existing service systems and will they be able to meet the needs in the long term?

- What will the impact of service systems be on the social and economic spheres and the environment?

- When and how will service sustainability be achieved? (Local Agenda 21, 1996).

By analysing colleges' mission statements according to the above-mentioned questions, it can be said quite convincingly that the answer to the second question is to "provide a quality service". For example, educating and training professional, high-level specialists in the field of chemistry, pharmacy, biotechnology, environment, food and their related industries meeting the requirements of sustainable and high-quality education in the modern technology environment in educational programmes with high value added /OMTC/. Mission of Riga Medical College of the University of Latvia: to enable students to acquire high-quality education and professional qualification through implementation of achievable results-based study programmes. Mission: To provide high-quality higher and general professional education in line with the demand of the national economy /JAC/.

Analysing the colleges' mission, it has been found that most of them, $80 \%$, also include the answer to the question "What will the service system influence be on the social and economic spheres and the environment?" Virtually, all contained one idea "the labour market will be provided with professional, competitive professionals", thus providing Latvia economy with the specialists, who promote the competitiveness of the industry and are competitive both in the local and international labour market (RBC). The mission is to educate and train highly skilled, qualified and competitive specialists in the field of health and social care, who will provide a solid basis for lifelong learning (Riga 1st Medical College). .... to educate and train talented and creative professionals in the business and culture for the labour market (Alberta College). The mission of the College of Law is to educate and train qualified specialists who have acquired not only good theoretical knowledge but also practical skills for the labour market of Latvia.

Having evaluated the mission statements of all colleges, it can be seen that most of them, practically all, are based on the same strategic planning model. And in such cases, the 
effectiveness of the method decreases and it is no longer a source of competitive advantage. According to the scientific literature, planning balance is important for the successful implementation of the company's mission, and in this case we can also attribute it to the planning balance among all 25 colleges.

"Vision is the highest expectations and ideals of the organisation, what the organisation is willing to become. The formulation often describes the organisation's elevated, even romantic and mythical nuances" (Leigh N., 2007). When assessing colleges' vision, it can be stated that most colleges are self-confident, which is also reflected in their formulated vision. "To be in the top three colleges in Latvia; to educate and train skilled specialists required for the labour market; to ensure the growth of the college, by gaining international experience and continuously improving the quality of studies" /the College of Law/. "Riga Technical College in 7 years will become the technical education, culture and cooperation centre for professionals, businesses and industries, as well as the stakeholders." "A modern, prestigious college with an attractive communication and cultural environment, solid professional basis that implements and develops sustainable vocational education in the health and social care sector." /Riga 1st Medical College/.

As Neville Leigh (2007) has noted, vision is a goal of ideals that serves as a landmark for what to strive. Do the vision statements of all colleges include these ideas? Colleges' vision statements undeniably include certain goals. However, they do not always reflect a goal of ideals. Two colleges in their vision are willing to be in the top three colleges in Latvia. Why not the first? The vision of Riga Medical College of the University of Latvia is not directed to an ideal goal achievement, i.e., Riga Medical College of the University of Latvia is a recognized higher education institution that implements first-level professional higher education study programmes, as well as the mission of Jekabpils Agribusiness College manifests comprehensive growth and stable positions among professional higher education institutions.

At the same time, the Business Management College is convincing in its vision - To become the leading distance education business school in Latvia and the Baltics.

\section{Conclusion}

Although many definitions of mission and vision can be found, usually mission and vision can be comprehended as something that organisation is currently, and what it would like to be. As definition of mission testify it is one of the steadiest characterising elements of the organisation, which formulate the purpose, the main long - term objectives and efforts of the organisation. Traditionally mission is expressed in one inspirational sentence. In practice, the formulation of mission and vision takes place simultaneously. However, formulating the mission and vision of a college, it would still be important to avoid duplication of information; some colleges reflect the same information in their mission and vision, i.e., to educate and train qualified specialists for the labour market, to educate and train competent specialists etc. Within the framework of the study, it has not been identified, which methods are used by the colleges in the development of their mission and vision. Only a subjective assessment has been performed as a result of the analysis of the mission and vision statements formulated by the college management, founders. To properly formulate the mission and vision, it would be advisable to create a working group - a team that brings together different opinions, proposals, ideals that would be reflected in the common material, discussed and the "core" would be extracted. 


\section{References}

1. Darba tirgus petijums „Profesionalas un augstakas izglitibas programmu atbilstiba darba tirgus prasibam” (Labor market research "Compliance of vocational and higher education programs with labor market requirements). (2007).

Retrieved: http://www.Im.gov.Iv/upload/darba_tirgus/darba_tirgus/petijumi/profesionala_augstaka_izglitiba .pdf. Access: 01.02.2018.

2. Dimensions of sustainable development.

Retrieved: http://www.unesco.org/education/tlsf/TLSF/theme_a/mod02/uncom02t02.htm . Access: 02.05.2017.

3. Drucker, P. (1971). Management: Tasks, Responsibilities and Practices. New York: Harper\&Row. 1971.

4. Dzedons, A. (2003). Strategiska vadisana (Strategic management). Riga: Kamene. 2003.

5. King, W.R., Clelland, D.J. (1979). Strategic Planning and Policy. Van Vostrad Reinhold. 1979.

6. Klaus, A. (2002). Zinibas vaditajam (Knowledge for manager). Riga: Preses nams. 2002.

7. Kochanova, R. (2012).Strategic Management System for providing sustainable development of organization. Retrieved: https://dspace.lu.Iv/dspace/bitstream/handle/7/4860/34914Raja_Kocanova_2012.pdf?sequence=1. Access: 02.01.2018.

8. Leight, N. (2007). Strategiska planosana (Strategic planning).Riga: SIA Multineo. 2007.

9. Misija, vizija un vertibas ir jakomunice (Mission, vision and values).

Retrieved: http://www.springvalley.Iv/lv/aktuali/publikacijas/misija-vizija-un-vertibas-ir-jakomunice/ Access: 01.02.2018.

10. Nipers, J., Zids, O., Kuklis, J. (2012). Profesionalaja izglitība iesaistīto visparizglitojošo macibu prieksmetu pedagogu kompetences paaugstinasana (Increasing the competence of teachers of general education subjects involved in vocational education).

Retrieved: http://profizgl.lu.Iv/pluginfile.php/36205/mod_resource/content/0/3_modulis/O_Zida_materials. pdf. Access: 20.01.2018.

11. Stevan, R. Covey. (2008). Astotais paradums. No efektivitates lidz izcilibai (Eighth habit. From efficiency to excellence). Riga: Zvaigzne ABS. 2008. 